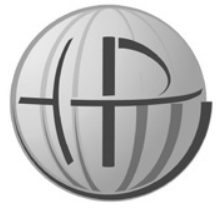

Horyzonty Polityki 2020, Vol. 11, No 36

\section{Pawee Armada}

http://orcid.org/0000-0001-5702-903X Akademia Ignatianum w Krakowie Instytut Nauk o Polityce i Administracji pawel.armada@gmail.com

DOI: 10.35765/HP.1962

OPEN ACCESS

\title{
Imperium wiedzy interesownej (impresja o dokonywaniu się pewnych procesów w skali globalnej)
}

\section{Streszczenie}

CEL NAUKOWY: Zwrócenie uwagi na szczególne walory poznawcze sytuacji wynikłej z (powszechnej percepcji) globalnego zagrożenia epidemicznego.

PROBLEM I METODY BADAWCZE: Unaocznienie dystansu pomiędzy elitą ekspertów, mających wpływ na zachowania decydentów bądź wykorzystywanych do uzasadnienia ich decyzji, a ogółem społeczeństwa, żyjącego w warunkach tzw. demokracji medialnej, które zdaje się w coraz większym stopniu opanowane przez postawy irracjonalne i przeniknięte nieufnością do nauki. Badanie tego procesu - stanowiącego być może kluczowy aspekt rozejścia się demokratycznej praktyki z teorią państwa nowoczesnego - wymaga z jednej strony obserwacji i analizy przekazów medialnych, z drugiej-uważnego namysłu nad niektórymi przykładami diagnozy nowoczesności, antycypującymi obecny stan rzeczy. Zdaniem autora, szczególną rolę może tutaj odegrać spuścizna myślicieli amerykańskich z 1 . połowy XX wieku.

PROCES WYWODU: Autor zaczyna od spostrzeżeń dotyczących sposobu relacjonowania w mediach stanowiska ekspertów dotyczącego „,walki z koronawirusem", by następnie przejść do uogólnień na temat roli mediów oraz wykształconych elit. Kolejne szczeble wywodu wiążą się z przywołaniem odpowiednich fragmentów diagnozy nowoczesnego państwa i społeczeństwa, formułowanych przez: Saula Bellowa, Christophera Lascha, Waltera Lippmanna, Roberta Shafera, Irvinga Babbitta, Paula Elmera More'a i George'a Santayanę. W trzeciej części eseju stara się powrócić do zarysowanych wcześniej uogólnień, kładąc 
dodatkowy akcent na specyfikę doświadczenia polskiego (jednocześnie uzasadniając czerpanie z dorobku myślicieli amerykańskich).

WYNIKI ANALIZY NAUKOWEJ: Wnioski z powziętych rozważań mogą dotyczyć: a) relewantności humanistycznej diagnozy nowoczesnego państwa i społeczeństwa (budowanej na podstawie refleksji wokół konieczności zbudowania nowych form arystokracji w ramach ustroju demokratycznego), b) realności procesów zachodzących w skali globalnej, podważających demokratyczne consensus wskutek dominacji postaw irracjonalnych, c) konieczności wykorzystania tego rodzaju refleksji (dotyczącej wiedzy i rozumności) dla celów związanych z wychowaniem obywatelskim.

WNIOSKI, IN NOWACJE, REKOMENDACJE: Tekst stanowi zachętę do refleksji badawczej, niestroniącej od inspiracji z zakresu historii idei, nad zmienną kondycją współczesnej demokracji, której istotne - problematyczne - cechy stają się szczególnie widoczne w sytuacji powszechnego zagrożenia (ewentualnie powszechnej percepcji zagrożenia). Taka refleksja powinna jednakże wiązać się nie tyle z samymi potrzebami intelektualnymi, ile z poczuciem odpowiedzialności wobec współobywateli, na ogół nieznających korzyści z udziału w racjonalnej debacie publicznej.

\section{SŁowA KLUCzowe:}

pandemia koronawirusa, eksperci, demokracja medialna, przywództwo, nowy humanizm

\section{Abstract}

\section{MERCENARY KNOWLEDGE EMPIRE (AN IMPRESSION ABOUT CERTAIN PROCESSES TAKING PLACE ON THE GLOBAL SCALE)}

RESEARCH OBJECTIVE: The aim is to draw scholars' attention to special cognitive merits of the situation that derives from (the common perception of) the global epidemic threat.

THE RESEARCH PROBLEM AND METHODS: The problem consists in bringing to light of the distance between the elite of experts - who either exert influence on actions taken by the decision makers or become used by the latter in order to justify their decisions - and the general public living under conditions of the so-called "media democracy" which mean, at it seems, the gradual predominance of the irrational attitude as well as distrust of the science. To study this process - one that probably indicates the key aspect of parting ways between the practice of democracy and the theory of modern state - requires not only some observation and analysis of the media coverage but also a careful reflection on some cases of the diagnosis of modernity, insofar as they had 
anticipated the present-day situation. And this may be the case of a couple of American thinkers from the 1 . half of the 20th century.

THE PROCESS OF ARGUMENTATION: “The article begins with some notes on the actual media coverage of experts talking about the "fight against coronavirus," and then we confront some useful generalizations about the role of mass-media and educated elites. In the course of the argument there are references to passages providing examples of the diagnosis of the modern state and society by Saul Bellow, Christopher Lasch, Water Lippmann, Robert Shafer, Paul Elmer More, and George Santayana. In the third part of the essay we return, in a mode, to the previous generalizations, while putting stress on a peculiarity of Polish experience (that should, nevertheless, turn out to be related to the legacy of American thinkers as mentioned above).

RESEARCH RESULTS: They can be given as the following suggestions: a) the humanistic diagnosis of the modern state and society (based on the considerations about forms of aristocracy desirable from the democratic point of view) remains relevant to us, b) what we witness are real processes, taken place all over the globe, which undermine the consent (upon which democracy rests) since irrational attitudes now become prevalent within what happens, c) any serious reflection on that matter (i.e., the political meaning of knowledge and rational discourse) must be connected with goals on the field of citizens' education.

CONCLUSIONS, INNOVATIONS AND RECOMMENDATIONS: This text is, above all, the attempt to encourage scholars to reflect, having inspiration from the history of ideas, on the changing condition of contemporary democracy. Its crucial - and troublesome - features become clear especially in the context of universal threat (or universal perception of such a thing). The reflection in question should not be treated as merely a response to our intellectual desires revealing, instead, the sense of responsibility for our fellow citizens who are mostly unconscious of the true value of rational public debate.

\section{KEYWORDS:}
2020 coronavirus pandemic, experts, media democracy, leadership, New Humanist Movement

Opowiadania o tym, jak będzie wyglądał świat po koronawirusie, są warte tyle, co wszelkie wróżby i ziemskie proroctwa. Nie znaczy to jednak, że możemy jedynie zamilknąć. Zaistniała bowiem sytuacja zdaje się sprzyjać dokonywaniu trafnych spostrzeżeń na poziomie ogólnych, „wzniosłych” intuicji, które w normalnych warunkach ulegająjakby rozproszeniu. Sumienie badacza każe mu zazwyczaj nie tylko unikać zbyt radykalnych sądów, ale i nie podejmować kwestii 
„za poważnych" - takich, co do których można by sądzić, że jego umysł nie podoła ich rozpatrzeniu. Na co dzień, innymi słowy, bezmierny przepływ niezliczonej liczby faktów i opinii onieśmiela nawet tęgie głowy. Tu zaś raptem następujące zdarzenia zmuszają nas do koncentracji nie na małym wycinku rzeczywistości, lecz na czymś, co ma wymiar - dosłownie - globalny. Chcąc nie chcąc, rozglądamy się wokół... całej Ziemi. I co widzimy?

Na pewno nie widzimy zarazków. Również niewielu z nas styka się bezpośrednio ze skutkami choroby i pracą tych, którzy likwidują jej skutki. Natomiast możemy - i zapewne powinniśmy - obserwować ludzkie reakcje na koronawirusa oraz reakcje na nie ze strony decydentów bądź, szerzej, osób mających taki czy inny wpływ na opinię publiczną. $Z$ tej perspektywy najbardziej palący staje się problem docierających do nas informacji, których ocena - nawet nie ścisła weryfikacja, lecz właśnie ocena w takim bardziej potocznym sensie - jest czymś trudnym albo i niewykonalnym. Nie mamy przecież wiedzy eksperckiej. Możemy, owszem, starać się ocenić konstrukcję czyjejś wypowiedzi, jej logiczną spójność, nasycenie "twardymi" danymi czy po prostu „urodę" słowną ale to tylko tyle. Odnośnie do meritum zagadnienia - czyli przede wszystkim pytania o to, czy środki podjęte „w walce $\mathrm{z}$ wirusem" są adekwatne do skali i istoty zagrożenia - jesteśmy zdani na emocje. Jakkolwiek utemperowane (zakładamy przecież, że jako badacze spraw ludzkich zwykliśmy nad sobą panować), to jednak emocje decydują o naszej aprobacie dla naukowych ustaleń, zaufaniu do adeptów wirusologii (bądź epidemiologii) i uznaniu poczynań władz, które - podobno - kierują się wiedzą uzyskaną od naukowców. Czy zatem jest tu jakieś miejsce na to, by "racjonalnie” wątpić?

Wydaje się, że... jak najbardziej. Posłużmy się prostym przykładem z okresu „narodowej kwarantanny". Oto trzy „wiodące” portale internetowe zdecydowały się zapoznać swoich czytelników z opinią "międzynarodowych ekspertów”, wypowiadających się w Internecie za pomoca ",organizacji EndCoronvirus". Owi eksperci zdołali podzielić kraje (wszystkie!) „,na trzy grupy”: „,wygrywających z epidemią”, będących „na dobrej drodze” oraz resztę - najbardziej zagrożonych (i siejących zagrożenie). Do pierwszej kategorii zaliczono m.in. Chiny, Australię czy Słowację; do drugiej - Francję, Niemcy, Włochy, Hiszpanię; do trzeciej, obok np. Brazylii czy Indonezji, 
Polskę. Kryterium klasyfikacji sprowadza się do pomiaru „tendencji spadkowej" zakażeń, a konsekwencje - dla tych, którym wedle specjalistycznych obliczeń „nie spada” (i nie zanosi się na „spadanie") - powinny obejmować dalsze surowe obostrzenia; w żadnym razie - luzowanie "reżimu sanitarnego". W praktyce to choćby inne traktowanie obywateli tych państw (odpowiednik izolacji wewnątrz społeczeństw) - dla dobra wspólnoty międzynarodowej należy ograniczyć kontakty z nimi ${ }^{1}$.

I co zrobić z takim przekazem? Od razu widać dwa problemy. Po pierwsze, jest to przedstawienie rzeczywistości - „nieintuicyjne” (w potocznym sensie, czyli że „na oko” sprawy wyglądają inaczej). Oczywiście, jako ludzie wykształceni, wiemy że „intuicja” może nas zawodzić; dla nas wszak Słońce porusza się po horyzoncie, Ziemia zawsze stoi. Tu jednak dysonans nie pojawia się na poziomie zaufania do zmysłów, lecz dostępu do informacji, które przecież nie zostały zakwestionowane przez „ekspertów”. Chodzi rzecz jasna o ogromną dysproporcję pomiędzy liczbą zachorowań i zgonów w Polsce oraz np. w Hiszpanii. Skoro nie osiągamy - na szczęście! - tego samego pułapu, to dlaczego mamy przykładać te same miary do zupełnie różnych stanów rzeczy? Po drugie zaś, należy spytać o samych „ekspertów”: czy są oni rzeczywiście bezstronni? Możliwe jest bowiem łączenie kompetencji w opracowaniu danych i nieuczciwie formułowanych wniosków. Zauważmy, że postulat dalszych obostrzeń, a szczególnie izolacji „,złych” krajów, wymaga akceptacji skrajnie niekorzystnych skutków gospodarczych i społecznych. Ktoś zostaje napiętnowany $\mathrm{i}-\mathrm{w}$ razie przyjęcia tej diagnozy - skazany na upośledzenie. Ktoś inny, być może, korzysta na tym.

Powyższy przykład, zaczerpnięty z doniesień medialnych (które zawsze na "coś" wpływają), każe przemyśleć osobliwość sytuacji, w jakiej się znaleźliśmy. Osobliwość ta nie stanowi rezultatu pandemii (ani reakcji na pandemię). Możemy raczej mówić o szczególnym

1 Por. URL = https://portal.abczdrowie.pl/jak-rozne-panstwa-walczaz-koronawirusem-polska-wsrod-najslabszych; URL = https://www. medonet.pl/koronawirus/koronawirus-na-swiecie,z-jaka-skutecznosciapanstwa-swiata-radza-sobie-z-koronawirusem-podzielono-je-na-trzygrupy,artykul,67284962.html; URL = https://wiadomosci.gazeta.pl/wiado mosci/7,173952,25929512,polska-nadal-nie-wygrywa-z-epidemia-covid-19jestesmy-w-gronie.html\#s=BoxOpMT (dostęp: 2020.07.06). 
momencie pełnego unaocznienia zjawiska, które towarzyszy nam od dawna. Zarazem można brać pod uwagę wiele zmiennych, jak starzenie się społeczeństw czy wpływ kultury masowej. Ale, tak czy owak, sedno zagadnienia zawiera się $\mathrm{w}$ naszym podporządkowaniu wobec „narracji” eksperckich. Świadectwa owego podporządkowania są tak liczne, i przede wszystkim „oczywiste”, że w zasadzie powinniśmy, jako badacze, być wdzięczni za wszelkie momenty „lepszej widoczności”.

Owszem, sama potrzeba uwzględnienia roli ekspertów nie jest przez nikogo negowana. Na niwie politologicznej zdajemy sobie sprawę chociażby z wagi tzw. ratingów państwowej „wiarygodności”, ogłaszanych raz po raz przez „agencje ratingowe”, czyli ciała eksperckie. Nie trzeba również głębokiej refleksji, by przedstawić sobie sytuację decydentów (pochodzących z wyboru i zależnych przeto od koniunktury): oni przecież także są odbiorcami „dramatycznych obrazów"; otrzymują "sygnały” i ulegają presji opinii publicznej, czyli swoich rozemocjonowanych wyborców. Ich z kolei (decydentów) powołanie się na autorytet ekspertów służy legitymizacji decyzji, które jawią się odtąd jako racjonalne czy „naukowe”. Jeżeli jednak skłaniamy się do tego, by traktować politykę jako nade wszystko obszar ścierania się (zmiennych) interesów, to nie jest bynajmniej nieracjonalnym pytanie: czy nie sprowadza się to wszystko do snucia interesownych ",narracji”, które opłaceni eksperci mieliby jedynie ex cathedra potwierdzać i uwiarygodniać? Gdzie nauka jest tylko... instrumentum regni?

W sumie splatają się tutaj dwa wątki: po pierwsze - oceny tego, co dociera do nas z ustaleń ekspertów; po drugie - oceny samego sposobu „docierania” tych ustaleń, obiektywizmu i wartości „obowiązującego" przekazu. Ujmując to na przykładzie "globalnego kryzysu klimatycznego": po pierwsze, należałoby oszacować udział czynników antropogenicznych w wywoływaniu zmian klimatu i ewentualnym zapobieżeniu skutkom tych zmian; po drugie, należałoby wyjaśnić, dlaczego to trudne zagadnienie przedstawia się $\mathrm{w}$ taki, a nie inny sposób; dlaczego, mówiąc najkrócej, twarzą walki o przetrwanie planety ma być nastoletnia Greta Thunberg, wątpliwości zaś w tej sprawie zrównuje się - niemalże lub dosłownie - z „negacjonizmem” Holocaustu... Tak jakby można było na serio powiązać interpretację (być może trafną) zjawisk zachodzących w przyrodzie ze stosunkiem 
(moralnym) do zbrodni, jaką „ludzie ludziom zgotowali” w warunkach totalitarnej wszechwładzy. Gdzie zatem kończy próba stanowienia reguł dyskursu, a zaczyna - emocjonalna perswazja? Kto i kiedy decyduje o tym, że racjonalne przekonywanie traci sens, że odbiorca nie jest zdolny do oceny "przedmiotu”, że w związku z tym pozostaje opcja jego podporządkowania „podmiotom” myślącym za niego?

Wątpliwości, które staramy się wydobyć na światło dzienne, mogą wydawać się tworzywem tekstów raczej publicystycznych niż naukowych opracowań. To jednak właśnie „w dobie koronawirusa” zadanie dla badacza - sprawdzić, z czego wynika wątpienie (oraz rodząca się na tej podstawie troska o demokrację bądź, w innym ujęciu, o losy naszego państwa i społeczeństwa). Szukając pożytecznej metafory, możemy mówić o zastrzyku nieufności, jaki trafia do wyobraźni obywatela. Jednocześnie - na szczęście dla badacza - daje się owo zagadnienie sprowadzić do dwóch tez, dotyczących tego, co „ujawnia" obecna sytuacja.

Ujawnia mianowicie:

a) pogłębiający się dystans między elitą formalnych decydentów i osób wpływowych (czyli np. publicystów), generalnie odwołujących się w swoich poglądach do wiedzy eksperckiej, oraz szeroką masą odbiorców (opinii publicznej), od których nie oczekuje się zrozumienia i przemyślenia podawanych informacji, a raczej aprobaty dla nich, podporządkowania, reakcji emocjonalnej;

b) brak instancji, która mogłaby sprawdzać zarówno konkretne wypowiedzi ekspertów, jak i całe obowiązujące "narracje” (zakładamy, że zewnętrzna zgodność - z punktu widzenia zwykłego obserwatora - tych wypowiedzi i „narracji” nie jest sama przez się dowodem ich prawdziwości, rzetelności czy przydatności dla ogółu; wiemy skądinąd, że ludzie także ci solidnie wykształceni i dobrze sytuowani - mogą ulegać powszechnie odczuwanym złudzeniom, modom czy schematom ideologicznym; mogą też, rzecz jasna, działać w imię partykularnych interesów środowisk, z których się wywodzą).

Nic nowego? Tak, to w pewnym sensie evergreen humanistycznych niepokojów. Nie traci przecież nic na aktualności diagnoza sformułowana na progu lat 90. przez amerykańskiego pisarza-noblistę, Saula Bellowa: 
prawda jest taka, że znajdujemy się w stanie zamętu, nieznośnego rozproszenia uwagi. Stoimy obecnie przed obliczem rewolucji informacyjnej (...) urbanizacja i technika bezsprzecznie dominują na naszej planecie. Powstało społeczeństwo światowe (...) Media (...), których obowiązkiem jest informować nas o tych nowych okolicznościach, nie mają pojęcia, co się dzieje. Nie ma wątpliwości, że - mówiąc potocznie - „nie łapia, o co biega”. Technika, która dysponuja, należy do cudów świata - dla inżyniera jest ucieleśnieniem piękna - lecz obsługujące ją umysły pozostają daleko w tyle za komputerami i satelitami. Pewien kalifornijski profesor obliczył, że przeciętne wydanie „New York Timesa" z dnia powszedniego zawiera więcej informacji niż osoba współczesna Shakespeare' owi gromadziła ich w ciągu całego życia. To możliwe, ale podejrzewam, że wykształcony elżbietańczyk miał w głowie mniejszy mętlik niż my. W przeciwieństwie do naszej jego wiedza nie znajdowała się na granicy chaosu (...) w życiu publicznym wszyscy (reagujący na chaos) posługują się tymi samymi formułami (...) prezenterzy sportowi, muzycy rapowi, uniwersytecka lewica, uniwersytecka prawica - wszyscy posługują się tym samym językiem, tymi samymi chwytami retorycznymi (...) rzecz jasna permanentny światowy kryzys, zwany chaosem obecnych czasów, nie jest dziełem mass mediów z ich rewolucją informacyjną. Media są jednak odpowiedzialne za naszą pseudowiedzę na temat wydarzeń, za głębię naszej ignorancji, za wewnętrzny zamęt i rozproszenie naszego pojmowania świata, za nasze niezdrowe podniecenie. Równie wielką odpowiedzialność ponoszą intelektualiści i uniwersytety (Bellow, 1994, s. 172-174, 177).

Mniej więcej w tym samym czasie inny amerykański myśliciel, Christopher Lasch, przestrzegał przed „,buntem elit”. Jego zdaniem ludzie znajdujący się na szczytach nowoczesnego - rzekomo demokratycznego - społeczeństwa zatracili poczucie odpowiedzialności czy też zobowiązania względem ogółu i zajmują się niczym innym, jak tylko pielęgnowaniem własnego dobrostanu. To nie masy - jak twierdził w latach 20. Hiszpan José Ortega y Gasset - „buntują” się przeciw zastanym ograniczeniom, to "nowe elity” przekraczaja, w swoim pojęciu, poziom "zwykłego życia”, co w rezultacie podważa, albo i usuwa, obowiązujące wszystkich consensus. O ile zatem Bellow martwi się - przede wszystkim - chaosem pożerającym umysły wewnątrz „demokracji medialnej”, o tyle Lasch każe nam myśleć, że ten chaos w gruncie rzeczy sprzyja skorumpowanym decydentom.

Obie diagnozy zdają się sprzęgać w miejscu, w którym pytamy o „realia” debaty publicznej; pytamy nie o to, czy dana konstytucja 
zawiera zasadę „,wolności słowa” (a która dziś nie zawiera takowej zasady?), ale też nie o pustą "wymianę poglądów”, stanowiącą co najwyżej okazję do wyrażania czyichś emocji, lecz o szanse spierania się na płaszczyźnie rozumowej i dochodzenia do zgody na podstawie argumentów. Według Lascha:

to (...) zanik publicznej dyskusji, a nie system szkolny (choćby nie wiem jak fatalny), powoduje, że ludzie na przekór wszystkim cudom Ery Informacji są niedoinformowani. Kiedy dyskusja staje się sztuką utracona, informacja - choćby łatwa do zdobycia - nie robi na nikim wrażenia. Demokracji potrzebna jest ożywiona dyskusja publiczna, a nie informacja. To znaczy informacja także jest jej potrzebna, ale tylko taka, której potrzeba wyrasta z dyskusji. Nie wiemy, czego nam potrzeba, dokąd nie postawimy właściwych pytań, a odkryć właściwe pytanie możemy jedynie wtedy, gdy nasze poglądy na temat świata poddamy testowi publicznej debaty (Lasch, 1997, s. 160).

Lasch dokonuje przy tym bardzo ważnego spostrzeżenia w wymiarze historyczno-ideowym, iż mianowicie:

debata polityczna zaczęła więdnąć na przełomie XIX i XX wieku - co ciekawe - dokładnie w tym samym czasie, gdy prasa zaczęła stawać się bardziej „odpowiedzialna”, bardziej profesjonalna i bardziej świadoma swych obywatelskich obowiązków (Lasch, 1997, s. 160-161).

Jest to pozorny paradoks. W ciągu poprzedniego stulecia celem mediów stało się bowiem nie dyskutowanie, lecz „skuteczne" informowanie odbiorcy. Państwo - a równie dobrze można by powiedzieć: „sprawna gospodarka" - nie czerpie siły z meandrów życia intelektualnego, lecz ze zgody na działanie; zgody powszechnej, opartej na powszechnym przyjmowaniu takich a nie innych opinii na temat rzeczywistości; opinii kojarzonych z „obiektywizmem” człowieka dobrze poinformowanego. Kluczowe okazuje się więc uznanie pierwszeństwa kryterium stricte politycznego, czyli skuteczności, wobec kryteriów debaty.

Jak pisze Lasch:

profesjonalizm $\mathrm{w}$ polityce oznaczał profesjonalizm $\mathrm{w}$ dziennikarstwie. Związek między tymi dziedzinami został rozszyfrowany ( $w$ latach 20.) przez Waltera Lippmanna (...) to Lippmann określił standardy, wedle których do dziś dokonuje się ocen prasy (...) zdaniem 
Lippmanna rola prasy polegała na puszczaniu w obieg informacji, a nie inspirowaniu dyskusji. Relacja między informacją i dyskusją była antagonistyczna, a nie komplementarna. Lippmann nie uważał, by wiarygodna informacja była koniecznym warunkiem wstępnym dyskusji. Wręcz przeciwnie; zdaniem Lippmanna informacja wykluczała dyskusję, czyniła ją zbędną. Do dyskusji dochodziło z powodu braku pewnej informacji (Lasch, 1997, s. 165, 167).

Zwrócenie uwagi na postać Lippmanna należy uznać za niebagatelną wskazówkę dla naszej teraźniejszej refleksji. Ten niezwykle wpływowy autor był wszakże nie tylko uważnym obserwatorem zmian, jakie zachodziły w pierwszych dekadach XX wieku, ale i współtwórcą tego, co jawi się obecnie jako utrwalony model „demokracji medialnej”, tj. model obowiązujący na Zachodzie i - przy wszelkich zastrzeżeniach, w rozmaitych zmutowanych wersjach - niemalże w każdym zakątku świata. Jego najważniejsza książka, Public Opinion (z 1922 roku), stanowi w istocie zapis rozczarowania (wciąż młodego człowieka) społeczeństwem, które odrzuciwszy więzy tradycji, wcale nie pragnie być społeczeństwem racjonalnym. Ludzie nie garną się do nauki podejmowania decyzji... i trudno mieć do nich o to pretensje, skoro wiedza potrzebna do ogarnięcia mechanizmów nowoczesnego państwa (bądź nowoczesnej gospodarki) jest, w coraz większym stopniu, wiedzą specjalistyczną. Sztuka polega na tym, by wyjaśnić im - może nie tyle całemu ludowi, ile wybrańcom demosu - co mają myśleć; myśleć - z pożytkiem dla siebie (ludu). W przeciwnym razie staną się (nieświadomymi) ofiarami własnej ignorancji.

Sedno diagnozy Lippmanna zawiera się w następującym cytacie:

wytwarzanie przyzwolenia nie jest nową sztuką. To bardzo stara sztuka, która miała zaniknąć wraz z pojawieniem się demokracji. Jednak nie zanikła. Prawdę mówiąc, poczyniła ogromne postępy (...) toczy się rewolucja, nieskończenie ważniejsza aniżeli jakiekolwiek przesunięcia władzy ekonomicznej. W ciągu życia pokolenia będącego teraz u władzy perswazja stała się samoświadomą sztuką i zwykłym narzędziem demokratycznych rządów. Nikt z nas nie zbliża się do rozumienia następstw tego zjawiska, ale nie jest nazbyt śmiałym proroctwem mówić, że wiedza o tym, jak wytwarzać przyzwolenie, zmieni wszystkie polityczne rachuby i przekształci każdą polityczną przesłankę. Pod naporem propagandy, niekoniecznie wyłącznie w złowieszczym znaczeniu tego słowa, dawne stałe naszego myślenia przeobraziły się w zmienne. Nie sposób już dłużej, 
dla przykładu, wierzyć w pierwotny dogmat demokracji, że wiedza potrzebna do zarządzania ludzkimi sprawami spontanicznie dobywa się z ludzkiego serca. Jeśli działamy w oparciu o taką teorię, to narażamy się na samooszukiwanie i na formy perswazji, których nie jesteśmy w stanie weryfikować. Zostało dowiedzione, że nie możemy polegać na intuicji, sumieniu czy przypadkowości potocznej opinii, kiedy mamy do czynienia ze światem poza naszym zasięgiem (Lippmann, 2020, s. 218), do którego docieramy jedynie za pomocą stereotypów.

Oznacza to, że najbardziej optymalna konstrukcja ładu politycznego (w warunkach nowoczesności) zależy w pełni od zachowania dysponentów wiedzy specjalistycznej czy naukowej-ekspertów. To nie „dobywająca się z ludzkiego serca” wola społeczeństwa (które może być, jako całość, omamione szkodliwymi stereotypami), lecz „wiedza” o kierowaniu państwem - lub, szerzej, o kierowaniu organizacją mającą cechy organizacji politycznej (ekonomicznej) - stanowi fundament "dobrej” polityki. W związku z czym to eksperci, odpowiednio zaangażowani i należycie słuchani (co powinny zapewnić media), są solą „,nowoczesnej” demokracji a nie - wybieralni decydenci. Kłopot oczywiście polega na tym, czy i w jaki sposób możemy być pewni, że nasi eksperci okażą się równocześnie kompetentni i bezinteresowni; że, innymi słowy, uda nam się dopilnować ludzi najlepiej poinformowanych (z dziedzin, które mają znaczenie dla polityki czy gospodarki), tak by nie byli specjalistami "na wynajem” i nie myśleli w kategoriach autopromocji czy „zabetonowania” własnych pozycji.

Problem wykształcenia elity, stanowiącej rozumny trzon społeczeństwa demokratycznego, jawił się jako palące zagadnienie w myśli amerykańskiej sprzed około stu lat. Można powiedzieć, że konsekwencje ówczesnego namysłu składają się na falę, która niesie nas do dzisiaj, będąc przedmiotem krytyki autorów, takich jak Lasch. Wyznacznikiem projektowania tejże fali stało się z jednej strony wyczerpanie dziewiętnastowiecznego modelu "tradycji dżentelmeńskiej” (genteel tradition), z drugiej - co widać dobrze u Lippmanna - rozbicie iluzji związanych z postępem (moralnym) ludzkości i obawa przed irracjonalnością zachowań decydentów; obawa boleśnie wzmocniona przez wydarzenia I wojny światowej i sytuacje powstałe w międzywojniu. Najlepszą bodaj rekapitulację podstawowej przesłanki 
tego rodzaju poszukiwań znajdujemy u innego uczestnika tamtych debat - humanisty Roberta Shafera:

powiada się, często i absurdalnie, iż ludzie epoki nowoczesnej całkowicie wyrzekli się wszelkich autorytetów, że nie będą brali niczego na wiarę, dlatego że coś im się każe, niczego co nie jest udowodnione, ta zaś nieznana dotąd wolność od przymusu stanowi zarazem oznakę i gwarancję postępu ludzkości. Jednakże w rzeczywistości ludzie są dzisiaj zależni od autorytetów bardziej niż byli ich ojcowie z poprzednich epok (...) to, co obecnie ma miejsce, polega na tym, że ludzie ślepo akceptująjakikolwiek autorytet przebrany w szaty "nauki”, ekscytując się próżną wiarą w „postęp", czy też samą ekspansją. Zachęcić ludzi, aby wyrzekli się autorytetu, znaczy tak naprawdę przekazać ich - niewiedzących i nieświadomych - w ręce następnego autorytetu, zdolnego przyjąć wiarygodne przebranie czy polecić im się składając popularne obietnice. $\mathrm{W}$ dziedzinie polityki mieliśmy w ostatnich latach przykłady tego procesu, na tyle dojmujące, by wzbudzić odrazę i przygnębić każdego, kto choćby odrobinę przejmuje się dobrem ludzkości. Jednak za często ci, którzy najgłośniej protestują przeciwko faszyzmowi we Włoszech i hitleryzmowi w Niemczech, okazują się gorącymi przyjaciółmi i obrońcami znacznie bardziej okrutnych, bezwzględnych i krwawych dyktatorów Rosji (Shafer, 1935, s. 231)².

Shafer - wraz z bardziej znanymi od niego przedstawicielami tzw. ruchu nowego humanizmu (New Humanist movement): Paulem Elmerem More'em i Irvingiem Babbittem (ten ostatni zresztą uczył na Harvardzie Lippmanna, który jednak do ruchu nie dołączył) poszukiwał formuły "odpowiedzialnego" przywództwa, zwanego niekiedy rządami „,naturalnej arystokracji”. W przeciwieństwie do nominalnych arystokratów z przeszłości, ci nowi mieli legitymować się nie "dobrym pochodzeniem”, lecz „wypracowaną" zdolnością samopoznania i samoopanowania; będąc panami samych siebie, zyskiwaliby "sprawiedliwy" tytuł do panowania nad innymi. Jest to, rzecz jasna, formuła wymagająca ustanowienia - na drodze zasadniczych zmian $\mathrm{w}$ podejściu do edukacji, ale także w szerszym wymiarze: transformacji kultury związanej z odnową klasycznego "doświadczenia humanistycznego i religijnego" - najwyższych standardów intelektualnych i etycznych. Wiemy dziś, że to się nie

2 Por. tegoż, Progress and Science: Essays in Criticism. New Haven-London 1922. 
udało. Zamiast "arystokratów” oglądamy, mówiąc z przekąsem, technokratycznych oligarchów.

Tym bardziej, jak się zdaje, warto przyglądać się ocenie przez humanistów tego, czemu chcieli oni przeciwdziałać. Ich krytyczne uwagi dotycza, owszem, konkretnych rozwiązań instytucjonalnych oraz rozmaitych idei („izmów”) tworzących dyskurs akademicki, przede wszystkim jednak celują w - dużo mniej uchwytne „po naukowemu" - procesy przemiany wyobraźni. Upraszczając to zagadnienie, można stwierdzić, że $-\mathrm{z}$ humanistycznego punktu widzenia - różnorodność poglądów (ideologii) czy form zaangażowania (ruchów) jest czymś względnym i niejako poślednim wobec (globalnej) dominacji takiego nastawienia (do życia), które zdradza zubożenie, wyjałowienie albo i zanik zdolności pojmowania tego, co wyższe z natury, prawdziwie uniwersalne, zaświatowe; co wyznacza (wysokie) standardy moralne i stwarza opór wobec działań instynktownych, mieszczących się w wymiarze naturalnej ekspansji człowieka (jak te związane $\mathrm{z}$ dążeniem do bogacenia się, a bardziej ogólnie - zdobywaniem przewagi nad innymi). W kontekście nauczania akademickiego oznacza to - według More'a - utratę wizji „długiego ciągu ludzkich dziejów" (gdzie to, co dawne, nie podlega „karze" wykluczenia z dyskursu tylko dlatego, że jest dawne, nienowoczesne), jak też umiejętności „odróżniania tego, co w nich istotne od tego, co efemeryczne”. Na uniwersytecie (początku XX wieku!)

olbrzymia przewaga studiów zajmujących się bezpośrednio pytaniami z zakresu ekonomii i rządzenia powoduje nieuniknione odizolowanie studenta od wielkiego dziedzictwa przeszłości; częsty zwyczaj ciągania go po slumsach socjologii - miast sprawić, by zadomowił się $\mathrm{w}$ towarzystwie szlachetnych umarłych - bądź to zatruwa jego umysł humanitaryzmem sflaczałym, bądź zapala do humanitaryzmu fanatycznego (More, 1915, Natural..., s. 36-37)

(„humanitaryzm”, będący właściwie antytezą prawdziwego „humanizmu", sprowadza się do quasi-religijnego traktowania wizji postępu i emancypacji jednostek czy grup społecznych).

Nie można przeto:

darzyć zaufaniem znacznego obecnie przerostu kursów dotyczących zarządzania i socjologii, po których idą w świat ludzie wyszkoleni w kierowaniu machiną państwową i z umysłami wyostrzonymi 
na bezpośrednie żądania szczególnych grup społecznych, ale bez prawdziwego treningu wyobraźni i bez zrozumienia szerszych problemów ludzkości (More, 1915, Academic..., s. 59).

Napięcie, do którego odnosi się More - jak się zdaje, bynajmniej nie przezwyciężone $\mathrm{w}$ dalszych fazach rozwoju „demokracji medialnej" - można ujać jako napięcie między wolnością i postępem (materialnym). Nie mamy tu na myśli, rzecz jasna, „wolności” zredukowanej do łatwego osiągania coraz to nowych pułapów "satysfakcji konsumenckiej". Dla ludzi cokolwiek obeznanych z duchem klasycznej filozofii - tak bardzo wymagającym ożywienia, aby kształcić w nim nowe elity - to oczywiste horrendum.

Jeśliby użyć jednego słowa na opisanie charakteru i życiowego powołania, których Platon i Arystoteles bronili, będąc rzecznikami swego ludu, byłaby to eleutheria, wolność: swoboda rozwijania tego, co w człowieku z natury wyższe - prerogatyw umysłu, pożądania prawdy, wyrobionego smaku - utrzymywania zaś w podległości tego, co niższe; jak również swoboda - w imię własnej doskonałości, albo raczej własnego istnienia - do tego, aby wymuszać zewnętrzne przystosowanie lub przynajmniej respekt wobec praw wewnętrznego rządu u innych, którzy nie rządzą się sami z siebie (More, 1915, Academic..., s. 61-62).

Przy obecnym stanie wyobraźni elit - zarówno decydentów sensu stricto, osób wpływowych, jak i zdecydowanej większości ekspertów - są to, Bogiem a prawda, puste słowa. Na nic zaś powoływanie się na mądrości klasyków (np. w imię promowania „postaw obywatelskich” czy „wrażliwości na dobro wspólne”), skoro nasze myślenie (polityczne) dawno temu uzależniło się od wyobrażeń całkowicie nieklasycznych. Ramy tych wyobrażeń określa coś, co najlepiej by nazwać „doświadczeniem nowoczesności”, co zaś - porządkowane przez historyków myśli politycznej - zapisuje się zwykle pod szyldem „liberalizmu”.

Trudno o lepsze ujęcie tego zagadnienia niż to, które sformułował inny ważny myśliciel pierwszych dekad poprzedniego stulecia, George Santayana. Pisze on:

umysłom starożytnych, którzy wiedzieli coś niecoś o tych sprawach, wolność i dobrobyt jawiły się jako niemalże nie do pogodzenia, gdy 
tymczasem nowoczesny liberalizm pragnie obu naraz. Liberałowie wierza, że swoboda dociekań, swoboda wynalazków, swobodne stowarzyszanie się i wolny handel na pewno wytworzą dobrobyt.

Starożytni, nieznający dobrodziejstw postępu naukowego (technologii), skłonni byli wręcz do przeciwstawienia wolności jako takiej postawie człowieka łaknącego dóbr materialnych.

Dobrobyt przynosi władzę; a kiedy ludzie sprawują kontrolę nad innymi ludźmi, to rządzenie obciąża nawet ich samych; jego machina nie daje się zatrzymać i ledwo co można w niej poprawić; rządzący lud staje się niewolnikiem swoich zobowiązań. Co więcej, dobrobyt wymaga nierówności funkcji i stwarza nierówności losu; wszak zarówno zbyt wiele pracy, jak i zbyt wiele bogactwa zabija indywidualną wolność. Pociągają one za sobą podległość wobec rzeczy; to zaś sprzeciwia się temu, co starożytni - posiadający dumę szlachetnych stworzeń - nazywali wolnością. Dobrobyt - tak indywidualny, jak i państwowy oznacza posiadanie; a znów to, co posiadamy, oznacza ciężary i uprząż niewolnika; w tym także niewolę umysłu, ponieważ następuje nie tylko przejęcie ludzkiego czasu, ale i uczuć, sądów i zakresu myślenia.

Co ciekawe, jedna z ilustracji tego zjawiska, podanych przez Santayanę, pasuje do naszych czasów zdecydowanie bardziej niż do jego:

często zastanawiam się, patrząc na moich bogatych przyjaciół, na ile to, co posiadaja, stanowi dla nich udogodnienie, na ile zaś - przeszkodę. Telefon jest, na przykład, udogodnieniem wtedy, gdy życzymy sobie być w wielu miejscach naraz i odnosić się do wszystkiego, co może się tam ukazać; jest przeszkodą gdy jesteśmy szczęśliwi tam, gdzie jesteśmy, robiąc to, co robimy (Santayana, 1922, s. 178-179).

Jednakże - kontynuuje Santayana:

być może liberalizm nie tyle aspiruje do tego, by pożenić wolność z dobrobytem, ile $\mathrm{z}$ - postępem. Postęp oznacza ciągłą zmianę na lepsze (...) lecz jaki byłby kierunek zmiany, aby wydała się ona liberałowi postępem? (...) kierunek, w jakim pragnęłaby zmierzać znaczna część - albo i większość - ludzi napełnia go niesmakiem i oburzeniem; w ogóle nie życzy im, by stali się szczęśliwi, chyba że staną się szczęśliwi na podstawie jego recept (...) trzeba im pomóc, ale nie tak zwyczajnie przy ich pragnieniach - to mogłoby się okazać dla nich bardzo złe - tylko pomóc iść naprzód, do góry, we właściwym kierunku. 
I jaki jest ten właściwy kierunek, rozpoznawany przez liberalne (postępowe) elity? To proste:

postęp (...) musi dalej zmierzać w kierunku, w którym podążał wiek dziewiętnasty - w stronę wielkich liczb, materialnej złożoności, jednakowości moralnej i ekonomicznej współzależności.

W praktyce - co warto podkreślić - conditio sine qua non tej nowoczesnej wizji świata jest to, że nie można nie aspirować do poziomu elit wykarmionych ową wizja; można aspirować niezdarnie, niepewnie, można nawet beznadziejnie, ale nie można nie aspirować wcale.

Jeśli nie godzisz się podążać w nakazanym kierunku, to nie jesteś po prostu inny - jesteś zatrzymany (w rozwoju) i przekręcony. Dzikus nie może pozostać dzikusem, zakonnica zakonnica, a Chiny nie mogą zachować swego muru (Santayana, 1922, s. 179-181).

Warto wspomnieć jeszcze o swoistym doprecyzowaniu tej wizji, jakie wyłania się z rozmowy Santayany ze słynnym potentatem naftowym Johnem D. Rockefellerem. Chodzi o „ideał monopolisty”, który dla nas byłby wszak niczym innym, jak streszczeniem dokonań globalizacji:

wszystkie narody muszą konsumować te same rzeczy - proporcjonalnie do liczby ludności. Po czym cała ludzkość wytworzy doskonałą demokrację - dzięki przydziałom wyznaczanym, jakoby dla ich dobra, przez pojedyncze centrum administracyjne; gdyż wówczas będą mieli zabezpieczenie wszystkiego, co zostało im przydzielone, po możliwie najniższej cenie (Santayana, 1945, s. 134-135). Czyż nie oddaje ten schemat - sprzed około stu lat - ducha naszej epoki?

Otóż w świecie zorientowanym według tego schematu narastać będzie zarówno uzależnienie od ekspertów, jak i skłonność do irracjonalnego buntu wobec ustaleń i decyzji odwołujących się do wiedzy eksperckiej (abstrahując od tego, na ile owa wiedza jest faktycznie uzyskiwana za pomocą metody naukowej; jak wiadomo, im dalej od „twardego jądra" fizyki i chemii, tym więcej wątpliwości „wewnątrz" nauki). Przywołani wcześniej humaniści pokazywali przekonująco, że rewersem wiary w postęp i powszechne zaspokojenie, kojarzone z nowoczesnością jest strach - tym bardziej widoczny, im bardziej 
nowoczesna wizja dobra chwieje się i im bardziej naruszone zostaje demokratyczne (państwowe, narodowe) consensus. Jak stwierdza More (w zbiorze esejów z 1921 roku):

pośród proletariatu to jest strach - nie całkiem nieuzasadniony - przed wyeksploatowaniem na zasadzie nieludzkich trybików w machinie; bo i cóż ma wspólnego - zapytają oni - naukowa ewolucja ze sprawami serca i ducha bądź ludzkimi nadziejami, radościami i smutkami? Toteż proletariat zaczyna grupować się jako armia walcząca przeciwko wyzyskiwaczom (...) może to zrujnować społeczeństwo; niczego wszak nie zbuduje. $Z$ drugiej strony, pośród inteligentnych i odnoszących sukcesy, strach ten przybiera postać humanitarystycznej skruchy; zrodziła się z tego moralność współczucia i ochłapów w miejsce powinności i kompetencji. Humanitaryzm (...) stanowi po prostu intelektualne przebranie społecznego instynktu strachu; to próba utrzymania ludzi w stanie podporządkowania za pomocą miłych słów. Nie ma co do tego żadnych wątpliwości. Instynktowny strach od wielu lat niepokoi władców i organizatorów społeczeństw (More, 1921, s. 251-252).

Jeśli godzimy się na to, by tak stare diagnozy uważać za wciąż celne i inspirujące dla nas, to oczywiście nie znaczy, żebyśmy nie dostrzegali różnic w naszym położeniu i położeniu Amerykanów z pierwszych dekad minionego stulecia. Nie można przecież abstrahować od zmiany technologicznej, jaką przyniósł Internet (a przedtem telewizja; Bellow, co łatwo skojarzyć, pisał o „rewolucji informacyjnej” w czasach rozkwitu „kablówek”); tak samo, jak nie da się zapomnieć o obawach związanych ze stanem środowiska naturalnego, nie mówiąc już o widmie użycia broni masowej zagłady. Niemniej rozsądne wydaje się mniemanie, że zasadniczy dylemat, przed jakim stawali cytowani myśliciele - dylemat kompetencji intelektualnych i moralnych ludzi panujących nad innymi, w obliczu nieziszczalnych nadziei płynących z doświadczenia nowoczesności nijak nie został usunięty czy przezwyciężony. Co więcej, ich spojrzenie może wydawać się świeższe, mniej „zmęczone” od naszego.

Summa summarum stwierdzamy bowiem, że współczesna „demokracja medialna" oznacza więcej i więcej tego samego, co w konsekwencji daje ów efekt rosnącego dystansu pomiędzy dysponentami wiedzy naukowej i „ludem”, w połączeniu z brakiem uznania dla uniwersalnego kryterium wiedzy (zarówno w sensie wiarygodności wiedzy, jak i dysponowania wiedzą; można w tym kontekście 
mówić o "postmodernizmie", ale też zastanawiać się nad „ceną postępu”). „Naukowość" - coraz bardziej wyspecjalizowana i skomercjalizowana - niejako rozpełza się w oczach obywatela-konsumenta. „Eksperci" są dobrzy o tyle, o ile są „nasi”. Ich celem jest nie tyle odkrywanie prawdy (czemu, w istotnym zakresie, służyłby dyskurs czy debata publiczna), ile - „nawigacja”.

„Nawigujemy" w świecie pełnym obiektywnych zagrożeń (jak np. zarazki), ale również w rzeczywistości społecznej czy politycznej, którą sami czynimy nieobejmowalną i nieznośną; czynimy ją taką jak się zdaje, w imię realizacji partykularnych interesów, swoich bądź obcych. Procesom tym odpowiada coraz większy udział ekspertów-prawników w podejmowaniu decyzji wiążących ogół obywateli. Toteż w "debacie publicznej”, z jaką mamy do czynienia, łatwo napotkać frazy w rodzaju "sąd zadecyduje" - nie: że „stwierdzi stan faktyczny" (np. o wyniku wyborów). Prawo, w powszechnym odczuciu, przestaje być norma, a staje jakby wyznacznikiem tworzywa procesów decyzyjnych oraz narzędziem kombinacji w ramach tychże procesów. Niebywała inflacja przepisów prawnych musi wszakże prowadzić do uznania kolejnych dziedzin życia za domeny wiedzy specjalistycznej (prawniczej). O ogarnięciu przez obywatela całych połaci regulacji nie może być mowy. Jest to niewątpliwie jeden z kluczowych aspektów rozchodzenia się teorii demokracji z praktyką zarządzania.

Zarządzanie z kolei staje się w ogromnej mierze zarządzaniem emocjami (mas ludzkich). Można wręcz mówić o uprawianiu swoistej „,sztuki behawioru”, w ramach której szczególnie ceni się strach. Ludzie - zgodnie z tym, co pisał More - boją się przede wszystkim siebie nawzajem; boją się, że zostaną wykorzystani przez silniejszych lub że staną się ofiarami zemsty ze strony słabszych. Perspektywa chorób i innych nieszczęść może jedynie wzmacniać tę wzajemną percepcję (bo czyż lęk przed zarażeniem nie konkretyzuje się do postaci lęku przed „bezobjawowymi” nosicielami wirusa?). Słowem, trudno oprzeć się wrażeniu, że dwudziestowieczne meandry nowoczesności zrodzić miały - stopniowo - świat Hobbesowski.

Biorąc to pod uwagę, warto również zastanowić się nad obecnym stanem głównych podmiotów nowoczesnej polityki. Zrozumiałe są opinie, że ostatnie wydarzenia - jeśli patrzeć na nie przez pryzmat konsolidacji społeczeństw w reakcji na epidemię - dowodzą siły, lub 
co najmniej żywotności, instytucji państwa narodowego. Lecz i ta ocena może mieć zwodnicze konotacje. To, że dane instytucje państwowe (raczej aniżeli ponadnarodowe) „radzą sobie z koronawirusem", dla wielu zapewne jawiąc się jako opoka, nie jest wszelako dowodem "suwerennego" działania tych instytucji - państwo może być silne w stosunku do obywatela (np. skutecznie egzekwując przepisy „narodowej kwarantanny”) i słabe w relacjach zewnętrznych, tj. z innymi państwami, organizacjami, a także strukturami własności prywatnej.

Być może, w obecnych warunkach, nie należy mówić o „suwerenności" (dyskusję nad tym zostawiamy na boku), a zamiast tego o - „podmiotowości” takich czy innych tworów politycznych. Łączymy wówczas ze sobą zasadnicze problemy, o jakich udało nam się wspomnieć w tym tekście: problemy związane $\mathrm{z}$ „demokracją medialną" i kształceniem elit; problemy, których ostatecznie wspólny rdzeń zawiera się w kwestii „relacji” pomiędzy wiedzą (teoretyczną) i decydowaniem za innych (w praktyce). Myśląc na tym poziomie, sięgamy do ustaleń wybitnych postaci sprzed stu lat - ludzi doskonale świadomych „podmiotowej” roli Ameryki jako arcynowoczesnego imperium, stanowiącego wzór dla całego świata.

Dziś, w naszym zakątku świata, zauważamy z jednej strony potencjał do myślenia podmiotowego (polska tradycja jest poniekąd tradycją sprzeciwu wobec obcych imperializmów, dążących do uprzedmiotowienia i zagospodarowania - „pod siebie” - tego wszystkiego, co postrzegają jako zasoby prowincji), z drugiej jednak utrwaloną skłonność do traktowania samych siebie jako wtórnych graczy, „uczniów” i naśladowców. Lata transformacji ustrojowej, będące okresem "dołączania do Zachodu”, sprzyjały pielęgnowaniu przeświadczeń, że jakoby inni wiedzą lepiej; proponowane przez nich wzorce materialnej ekspansji nie podlegają głębszemu zakwestionowaniu i jako takie zachowują dla nas moc dobroczynną. Nie chcemy, rzecz jasna, powiedzieć przez to, że jakiegoś rodzaju przeciwstawne ekstremum całkowitego odrzucenia „narracji” podtrzymywanych przez elity Zachodu doprowadziłoby z miejsca do rozwiązania "naszych" problemów z „naszą" demokracją. Chodzi o to, by konsekwentnie - na miarę rodzimej tradycji, ale i wykształcenia sięgającego źródeł „naszej” zachodniej cywilizacji - stawić czoła owej feralnej pokusie niemyślenia za siebie. 
Współczesny amerykańskim humanistom austriacki poeta Rainer Maria Rilke wyraził taką oto smutną myśl: „Nie dla nas wielkie słowa z czasów, w których dzieje widoczne były jak na dłoni. / Gdzież nam do zwycięstw? Przetrwać, oto wszystko". Otóż nie! Nie możemy dbać o to jedynie, aby przerwać na poboczu drogi, na której dokonują się wielkie procesy. Nie jest też rzeczą godną badacza unosić się na resztkach gasnącego dyskursu. Szukając odpowiedzi na najbardziej palące problemy można i należy zwracać się w stronę starożytnych czy średniowiecznych klasyków. Kto wie, czy nie nauczylibyśmy się dużo więcej na temat „prawdziwego” przywództwa, czytając dzieła opiewające wielkość posługi kapłańskiej (Jana Chryzostoma czy Grzegorza Wielkiego) aniżeli będąc „ciąganym po slumsach socjologii", by posłużyć się raz jeszcze złośliwą frazą More'a. To zaś nie wbrew potrzebom, jakie dostrzegamy na co dzień, ale właśnie dlatego, że potrzeba nam spojrzenia z zewnątrz.

Reasumując, są powody, by wykorzystać obecny czas na refleksję dotyczącą procesów zachodzących w skali globalnej. Wokół nas, z każdej strony, krajobraz pandemii, będący wszak - nade wszystko - widokiem ludzkiego strachu. Czy jest to widok pokrzepiający? Pewnie nie. Możemy jednak wierzyć w to, że poznając zagrożenia, poznajemy również szanse.

\section{Bibliografia}

Bellow, S. (1994). Rozproszenie uwagi. W: S. Bellow, Suma po przemyśleniach. Od niewyraźnej przeszłości do niepewnej przyszłości. Przeł. T. Bieroń. Poznań: Zysk i S-ka.

Lasch, Ch. (1997). Bunt elit. Przeł. D. Rodziewicz. Kraków: Wydawnictwo Platan.

Lippmann, W. (2020). Opinia publiczna. Przeł. J. Tegnerowicz. Kraków: Animi2.

More, P.E. (1915). Academic Leadership. W: P.E. More, Shelburne Essays Ninth Series: Aristocracy and Justice. Boston-New York: Houghton Mifflin Company.

More, P.E. (1915). Natural Aristocracy. W: P.E. More, Shelburne Essays Ninth Series: Aristocracy and Justice. Boston-New York: Houghton Mifflin Company. 
More, P.E. (1921). Economic Ideals . W: P.E. More, Shelburne Essays Eleventh Series: A New England Group and Others. Boston-New York: Houghton Mifflin Company.

Santayana, G. (1922). The Irony of Liberalism. W: G. Santayana, Soliloquies in England and Later Soliloquies. London-Bombay-Sydney: Constable and Company Ltd.

Santayana, G. (1945). The Middle Span, Vol. II: Persons and Places. New York: Charles Scribner's Sons.

Shafer, R. (1935). Paul Elmer More and American Criticism. New Haven-London: Yale University Press.

\section{Copyright and License}

This article is published under the terms of the Creative Commons Attribution - NoDerivs (CC BY- ND 4.0) License http://creativecommons.org/licenses/by-nd/4.0/ 